\author{
Tamás Körmendi
}

\title{
PRIPREME I VOJNI POHOD KRALJA (SVETOG) LADISLAVA I. U HRVATSKU*
}

Tamás Körmendi

Bölcsészettudományi Kar

ELTE

Budapest

\author{
UDK 929.731 Ladislav \\ 355.48(439:497.5)“109”(091) \\ Prethodno priopćenje \\ Primljeno: 9.5.2018. \\ Prihvaćeno: 1.6.2020. \\ DOI: https://dx.doi.org/10.21857/yl4okflp09
}

\begin{abstract}
Članak pokušava prikazati precizniju (ili bar nešto objektivniju) sliku o hrvatskom vojnom pohodu ugarskog kralja (svetog) Ladislava I. 1091. i uspostavi Zagrebačke biskupije. Prvo se istražuje je li zemlja između Drave i Gvozda pripadala prije tih događaja hrvatskom ili ugarskom kraljevstvu te se pokušava utvrditi najvjerojatniji datum uspostave Zagrebačke biskupije i razlog uspostave nove biskupije u tom području. Konačno, analiziraju se i moguće vanjskopolitičke okolnosti i ciljevi spomenutog vojnog pohoda sv. Ladislava.
\end{abstract}

Ključne riječi: Ladislav I. Arpadović (sveti Ladislav); Zagrebačka biskupija; Ugarska; Hrvatska; Slavonija; povijest 11. stoljeća

U ovom bih radu želio istražiti povode i okolnosti vojnog pohoda kralja svetog Ladislava u Hrvatsku 1091., događaja koji se može smatrati najuspješnijim poglavljem njegove vanjske politike. Naravno, toliko razgranatu i izuzetno važnu temu morat ću u okvirima ovog rada prikazati samo ukratko. Naime, moj cilj i nije podrobno prikazati svaku pojedinost, što sam inače već pokušao u radovima objavljenima na mađarskom jeziku, već predstaviti i sintetizirati rezultate mađarskih istraživanja u Hrvatskoj, jer su oni možda teže dostupni hrvatskim povjesničarima.

\footnotetext{
* Rad je izrađen uz potporu Nacionalnog ureda za istraživanja, razvoj i inovacije (Nemzeti Kutatási, Fejlesztési és Innovációs Hivatal, OTKA-K-115896) i istraživačke stipendije Bolyai János Kutatási Ösztöndíj. Autor je sveučilišni docent Sveučilišta Eötvös Loránd Tudományegyetem u Budimpešti i član Skupine za istraživanje mađarske srednjovjekovne gospodarske povijesti Lendület [Zamah] Centra za filozofska i humanistička istraživanja Mađarske akademije znanosti (MTA BTK).
} 
U tom ću smislu, saževši rezultate tri moja prethodna rada objavljena na mađarskom jeziku, ${ }^{1}$ pokušati izvesti i neke nove zaključke o tri pitanja: pripadnosti područja Slavonije (u kasnosrednjovjekovnom smislu riječi) u 11. stoljeću, osnutku Zagrebačke biskupije koji se po mom mišljenju može uvrstiti (i) u pripreme vojnog pohoda u Hrvatsku te o događajima samog pohoda - odnosno, smjestiti osvajački pohod u red vanjskopolitičkih težnji onodobnog Ugarskog Kraljevstva.

\section{Onodobna pripadnost Slavonije}

Jedna od središnjih tema povjesničarskih rasprava (katkad obojenih javnopravnim prizvukom), između Hrvatsko-ugarske nagodbe 1868. i prestanka državne zajednice dviju zemalja 1918., bila je pitanje je li "stara" Slavonija ${ }^{2}$ bila pod mađarskom ili hrvatskom upravom u 11. stoljeću, prije vojnog pohoda svetog Ladislava u Hrvatsku 1091. ${ }^{3}$ Raspadom Austro-Ugarske Monarhije ta je rasprava prekinuta, a pitanje se nije riješilo na odgovarajući način: možda prvenstveno iz toga proizlazi da znanost sve do danas nije mogla postići konsenzus oko tog problema. ${ }^{4} \mathrm{U}$ nastavku ću prvo ukratko sažeti rezultate kritičkog

1 Tamás Körmendi, Szlavónia korai hovatartozása [Rana pripadnost Slavonije], Századok, sv. 151, Budapest 2012., str. 371-383; isti, A zágrábi püspökség alapítási éve [Godina utemeljenja Zagrebačke biskupije], u: "Köztes-Európa" vonzásában. Ünnepi tanulmányok Font Márta tiszteletére [Privučena srednjoistočnom Europom. Svečani zbornik radova u čast Márte Font], ur. Dániel Bagi - Tamás Fedeles - Gergely Kiss, Pécs 2012., str. 329-341; isti, Szent László horvátországi háborújáról. Az 1091. évi hadjárat történetének forráskritikai vizsgálata [O hrvatskom ratu sv. Ladislava. Kritičko ispitivanje izvora o povijesti vojnog pohoda iz 1091.], Századok, sv. 159, Budapest 2015., str. 443-477.

2 Pojam Slavonije ovdje i u nastavku upotrebljavat ću u kasnosrednjovjekovnom smislu riječi, to jest pod njime podrazumijevam područje koje se prostire od zapadne polovine područja između Drave i Save te područje između Save i planine Kapela (Gvozd), uglavnom šire zagrebačko područje i njegova rubna gorja.

3 Vidi primjerice, bez pretenzija na iscrpnost: Frigyes Pesty, Az eltünt régi vármegyék [Iščezle stare županije], sv. 1-2, Budapest 1880., sv. 2, dok. 159, str. 163-171; Gyula Pauler, Horvát-Dalmátország elfoglalásáról (1091-1111) I. [O zauzimanju Kraljevine Hrvatske i Dalmacije (1091. - 1111.)], Századok (A Magyar Történelmi Társulat közlönye), sv. 22, Budapest 1888., str. 198-202; isti, A magyar nemzet története az Árpádházi királyok alatt [Povijest mađarskog naroda pod kraljevima iz kuće Arpadovića], sv. 1-2, Budapest 1899. ${ }^{2}$, sv. 1, str. 452 (bilj. 341); Vjekoslav Klaić, Slavonien vom X. bis zum XIII. Jahrhundert, Zagreb 1882., str. 12-14; János Karácsonyi, Halavány vonások hazánk Szent István korabeli határairól [O razvoju granica naše domovine od doba sv. Stjepana], Századok, sv. 35, Budapest 1901., str. 1057; isti, Szent László meghódítja a régi Szlavóniát [Sv. Ladislav osvaja staru Slavoniju], u: Értekezések a történeti tudományok köréből, sv. 24/2, Budapest 1916., str. 5-11; Bálint Hóman, A zágrábi püspökség alapítási éve [Godina utemeljenja Zagrebačke biskupije], Turul [A Magyar Heraldikai és Genealógiai Társaság közlönye], sv. 28, Budapest 1910., str. 109-112; Ferdo Šišić, Priručnik izvora hrvatske historije 1/1, Zagreb 1914., str. 322-345. Kratki pregled historiografije tog pitanja vidi u: Dénes Sokcsevits, Horvátország a 7. századtól napjainkig [Hrvatska od 7. stoljeća do naših dana], Budapest 2011., str. 73-77, 112-115; hrvatski prijevod: Dinko Šokčević, Hrvatska od stoljeća 7. do danas, Zagreb 2016., str. 47-51, 76-79.

4 Iz obimne literature o tom pitanju, također bez pretenzija na iscrpnost, vidi: György Györffy, Szlavónia kialakulásának oklevélkritikai vizsgálata [Kritičko ispitivanje isprava o postanku Slavonije], Levéltári Közlemények, sv. 41, Budapest 1970., str. 223-239; Nada Klaić, Povijest Hrvata u ranom srednjem vijeku, Zagreb 1975., str. 278-279, 288, 314; Gyula Kristó, A feudális széttagolódás Magyarországon [Feudalna fragmentacija u Ugarskoj], Budapest 1979., str. 85; Ivo Goldstein, Hrvatski rani srednji vijek, Zagreb 1995., str. 352; Neven Budak - Tomislav Raukar, Hrvatska povijest srednjeg vijeka, Zagreb 2006., str. 105. Ovdje 
ispitivanja navedenih izvora o ranoj pripadnosti područja između Drave i Gvozda, potom ću u grubim crtama opisati predodžbe koje se danas smatraju odlučujućima u istraživanju tog pitanja u Mađarskoj, a na koncu ću u nekoliko riječi predstaviti i vlastito stajalište.

Poznato je da je područje Slavonije u kasnosrednjovjekovnom smislu Ferdo Šišić, na temelju pet izvora, uvrstio pod upravu hrvatske države 10./11. stoljeća. ${ }^{5}$ Grupu izvora koje je on sabrao poslije je Nada Klaić - koja je inače bila mišljenja da je Slavonija samo u 10. stoljeću pripadala hrvatskoj državi, a u 11. stoljeću već se smatrala pograničnom zonom između Ugarskog i Hrvatskog Kraljevstva - proširila i šestim izvorom (djelom De administrando imperio inače pripisanim Konstantinu Porfirogenetu) govoreći o aspektima tog pitanja u 10. stoljeću. ${ }^{6} \mathrm{U}$ prijašnjem radu te sam izvorne tekstove i osobno ponovno stavio pod povećalo. ${ }^{7}$

Slijedom filološke analize po mom se mišljenju može reći da po pitanju hrvatske uprave na područjima između Drave i Gvozda nijedan od navedenih šest izvora ne izdržava kušnju kritičkog ispitivanja. Tumačenje odluka II. crkvenog sabora u Splitu održanog u pobliže nepoznatom vremenu, no sigurno prije $928 .{ }^{8}$ problematično je i s gledišta toponomastike i s onog crkvene uprave. ${ }^{9}$ Filološka i povijesna analiza referentnih odlomaka (to jest 13. i 30. poglavlja) ${ }^{10}$ djela koje se tradicionalno pripisuje bizantskom caru Konstantinu Porfirogenetu, poznatog pod naslovom De administrando imperio - čija je povijest nastanka prema najnovijim istraživanjima veoma zamršena - prije ukazuje na to da se granica između hrvatske države i mađarskoga plemenskog saveza već i sredinom 10. stoljeća protezala negdje u gorju Gvozd. ${ }^{11}$ Podatak iz 99. poglavlja djela Bečka ilustrirana kronika, koji se po mišljenju mađarske historiografije oslanja na neka starija ugarska gesta, a po kojem su se $\mathrm{Hr}-$ vati u vrijeme kralja Zvonimira borili protiv Karantanaca, ${ }^{12}$ vjerojatno nije spomen na karantanski napad na slavonska područja, već izvještava o sukobu koji je izbio

i u nastavku samo ću se veoma rijetko pozvati na hrvatsku stručnu literaturu, naime, prvenstveni je zadatak ovog rada predstaviti stajalište mađarskoga povijesnog istraživanja koje je hrvatskoj strani možda iz jezičnih razloga teže dostupno. U spomenutim radovima ponešto opsežnije ukazujem na historiografiju pojedinih pitanja, a, naravno, sigurno je i to da, unatoč svim svojim naporima, nisam mogao otkriti sve relevantne teze stručne literature (osobito hrvatske stručne članke do kojih se iz Mađarske veoma teško dolazi).

5 Šišić, Priručnik $1 / 1$, str. 338-345.

6 N. Klaić, Povijest Hrvata, str. 278-279.

7 Körmendi, Szlavónia, str. 371-383.

8 Codex diplomaticus regni Croatiae, Dalmatiae et Slavoniae. Diplomatički zbornik Kraljevine Hrvatske, Dalmacije i Slavonije, 18 sv., prir. Tadija Smičiklas et al., Zagreb 1904.-1990. (dalje: CD), sv. 1, str. 38-39.

9 Karácsonyi, Szent László, str. 7; isti, Horvát vakoskodás [Hrvatsko sljepilo], Századok, sv. 52, Budapest 1918., str. 344-345.

10 Constantine Porphyrogenitus, De administrando imperio, prir. Gyula Morvacsik, Corpus fontium historiae Byzantinae, sv. 1, Dumbarton Oaks 1967., str. 64, 142.

11 Karácsonyi, Szent László, str. 6; Györffy, Szlavónia kialakulása, str. 223. Usp. npr. N. Klaić, Povijest Hrvata, str. 284, 288; Lujo Margetić, Pitanja iz najstarije povijesti Zagrebačke biskupije i Slavonije, u: isti, Hrvatska i Crkva u srednjem vijeku. Pravnopovijesne i povijesne studije, Rijeka 2000., str. 300.

12 Scriptores rerum Hungaricarum tempore ducum regumque stirpis Arpadianae gestarum, sv. 1-2, prir. Emeric Szentpétery, Budapest 1937.-1938. (dalje: SRH), sv. 1, str. 363-364. 
na granici istarskih područja podvrgnutih pod vlast karantanskog markgrofa i zapadnih rubova primorskoga Hrvatskog Kraljevstva - o kojemu, naime, ima traga i u drugim izvorima. ${ }^{13}$ Ispravu kralja Andrije II. izdanu Zagrebačkoj biskupiji 1217. ${ }^{14}$ nakon kritička ispitivanja slobodno možemo smatrati patvorinom nastalom oko 1226./1227..$^{15}$ dio njezine formule narratio koji se odnosi na našu temu - po kojem je sveti Ladislav bio taj koji je "zemlju iliti banovinu Slavonije, preobrativši je s krivog puta idolopoklonstva na kršćanstvo, pokorio za Ugarsku krunu i u istoj banovini osnovao i biskupiju i samostan [ili kaptol] u čast Svetog Stjepana"16 - po pojedinim mišljenjima je optužena za svjesno krivotvorenje povijesnih događaja ${ }_{1}^{17}$ dok osobno ne bih isključio ni mogućnost da su je konstruirali pogrešno shvativši upravo gornji navod iz gorespomenute ugarske geste. ${ }^{18}$ Rani podaci velikog djela Tome Arhiđakona, poznatog pod naslovom Historia Salonitanorum atque Spalatensium pontificum i dovršenog između 1266. i 1268. ${ }^{19}$ također nisu oslobođeni sumnje: napomene u 15. i 17. poglavlju tog rada - da je, naime, duhovna jurisdikcija tzv. hrvatskog biskupa (episcopus Chroatensis) nekada dosezala sve do Drave i da je tek sveti Ladislav pripojio slavonska područja Ugarskoj ${ }^{20}$ - kasnijeg su nastanka, nepouzdana podrijetla i stoga nisu vjerodostojne. ${ }^{21}$ Naposljetku, povelja krivotvorena također na ime kralja Andrije II., bez datuma nastanka, ${ }^{22}$ po kojoj je kralj Ladislav "prvi prešao rijeku

13 N. Klaić, Povijest Hrvata, str. 378-379; Diplomata Hungariae antiquissima, sv. 1, prir. Georgius Györffy, Budapesti 1992. (dalje: DHA), sv. 1, str. 171.

14 CD 3, str. 147-149; Az Árpád-házi királyok okleveleinek kritikai jegyzéke [Kritičke bilješke o ispravama kraljeva iz kuće Arpadovića], sv. 1-2/4, prir. Imre Szentpétery - Iván Borsa, Budapest 1923.-1987. (dalje: RA), br. 323.

15 József Deér, A magyar-horvát államközösség kezdetei [O počecima ugarsko-hrvatskog državnog zajedništva], u: isti, Királyság és nemzet. Tanulmányok 1930-1947. [Kraljevstvo i narod. Studije 1930.-1947.], Historia Incognita, sv. 13, Máriabesnyő - Gödöllő 2005., str. 52-53, bilj. 68; Györffy, Szlavónia kialakulása, str. 230-234; Nada Klaić, Tobožnji Ladislavov "monasterium sancti Stephani regis" u Zagrebu, Peristil, sv. 24, Zagreb 1981., str. 39. Usp. npr. Lujo Margetić, O vjerodostojnosti isprava unesenih u potvrdnice pape Grgura IX. iz 1227. godine, u: isti, Hrvatska i Crkva, str. 328-333.

16 [...] monasterium Zagrabiense a sancto Ladizlao rege sanctissime recordationis predecessore nostro constructum, qui terram Sclavonie sive banatum ab errore ydolatrie ad christianitatem convertens corone Hungarie subiugavit, qui etiam in eodem banatu episcopatum instituit et monasterium in honore sancti regis Stephani (CD 3, str. 147).

17 Györffy, Szlavónia kialakulása, str. 234.

18 Körmendi, Szlavónia, str. 379-380.

19 Mirjana Matijević Sokol, Toma Arhiđakon i njegovo djelo. Rano doba hrvatske povijesti, Knjižnica hrvatske povijesti i kulture, sv. 3, Split 2002., str. 33-43.

20 Thomae archidiaconi Spalatensis Historia Salonitarum atque Spalatinorum pontificum, prir. Olga Perić - Damir Karbić - Mirjana Matijević Sokol - James Ross Sweeney, Central European Medieval Texts, sv. 4, Budapest - New York 2006. (dalje: Thomas Spalatensis), 70, 92.

21 Pauler, Horvát-Dalmátország, str. 201; isti, A magyar nemzet 1, str. 446.

22 Stručna literatura na tragu Józsefa Kollera (Historia episcopatus Quinqueecclesiarum, sv. 1-7, Posonii Pesthini 1782.-1812., sv. 1, str. 293) većinom je smješta u 1235. godinu, no u očuvanim primjercima nije naveden datum isprave (Magyar Nemzeti Levéltár Országos Levéltára [Budapest], Diplomatikai Levéltár; Diplomatikai Fényképgyűjtemény, no. 280274). 
Dravu i pripojivši ih svojoj zemlji prvi put zauzeo slavenske strane"23 - vjerojatno je nastala nešto prije 1343., možda upotrebom upravo rada Tome Arhiđakona ili (što se čini mnogo vjerojatnijim) Andrijine zagrebačke isprave patvorene s datumom 1217. godine. ${ }^{24}$

Dakle, na temelju kratkog pregleda svih šest izvora koji se inače navode za dokazivanje hrvatske uprave u 11. stoljeću nad Slavonijom u kasnosrednjovjekovnom smislu, s jedne strane moramo skrenuti pozornost na činjenicu da naši izvori najranije počinju pisati o tome kako Slavonija prije pohoda svetog Ladislava nije bila dio Ugarskog Kraljevstva tek oko 1226./1227., dakle, sa zakašnjenjem od dobrih sto pedeset godina. To da je područje pripadalo hrvatskoj državi, čak i u 13. stoljeću zapisuje samo Toma Arhiđakon - isti Toma Arhiđakon čiji su raniji podaci tijekom istraživanja na brojnim drugim mjestima pobudili vjerojatno utemeljene sumnje, te stoga opet moramo naglasiti da se hrvatska vlast između Drave i Gvozda sredinom 11. stoljeća ne može dokazati ni s pomoću ijednog od pregledanih izvora.

Ako izvori i ne dokazuju da je Slavonija u kasnosrednjovjekovnom smislu, u vremenu koje istražujemo, pripadala Hrvatskom Kraljevstvu, to samo po sebi naravno još ne mora značiti niti znači da je nužno moramo smatrati područjem pod ugarskom upravom. Brojni su znanstvenici u skladu s potonjim pretpostavili da je područje između Drave i Gvozda u velikom dijelu 11. stoljeća bila svojevrsna ničija zemlja između hrvatske i mađarske države. ${ }^{25}$ Nasuprot tomu, György Györffy je na temelju svjedočanstva jednog dijela teksta već spomenutog djela De administrando imperio, odnosno talijanskih izvora smatrao vjerojatnim da su šire zagrebačko područje i njegova okolica već početkom 10. stoljeća dospjeli pod mađarsku upravu, a do vremena osnutka države svetog Stjepana bili pod čvrstom mađarskom vlašću. ${ }^{26}$ Attila Zsoldos je argumentima upravne povijesti također tvrdio da se vlast ugarskih kraljeva vjerojatno već davno prije osvajanja svetog Ladislava protezala na Slavoniju u kasnosrednovjekovnom smislu. Kao prvo: ugarski kraljevi sve do 16. stoljeća nisu upotrebljavali naslov "kralja Slavonije" - a da je i to područje pod cijenu oružanih borbi dospjelo u ruke Arpadovića, onda bi se, slično Hrvatskoj i Dalmaciji, vjerojatno pojavilo i u vladarskim titulama. Kao drugo: na slavonskim područjima ukorijenile su se ugarske institucije kakvima u primorskoj Hrvatskoj i poglavito Dalmaciji nema ni traga - na prvom mjestu valja spomenuti županije. Ako se ugarska uprava u približno isto vrijeme učvrstila na području između Drave i Gvozda, odnosno u pri-

${ }^{23}$ cum [...] primus transiverit Drave fluvium, et partes sibi Sclavicas regno primum occupavit adducto, ubi et sedem fundavit episcopalem videlicet Zagrabiensem (CD 3, str. 445).

24 Pauler, A magyar nemzet 2, str. 590-593 (usp. CD 3, str. 445); Györffy, Szlavónia kialakulása, str. 234-235; Körmendi, Szlavónia, str. 381-382.

25 Npr. Karácsonyi, Halavány vonások, str. 1057; Hóman, A zágrábi püspökség, str. 109-112; Kristó, Feudális széttagolódás, str. 85; N. Klaić, Povijest Hrvata, str. 314. Prema Nadi Klaić područje između Drave i Gvozda do druge je polovine 10. stoljeća u potpunosti bilo pod hrvatskom upravom i tek je oko prijelaza u drugo tisućljeće prestalo biti pod nadzorom primorskog kraljevstva.

26 Györffy, Szlavónia kialakulása, str. 223-239. 
morju, što bi bio povod spomenutoj razlici? I kao treće: u ispravama iz doba Arpadovića nalazimo opipljive dokaze da su županije Južnog Zadunavlja, Zala i Šomođ (Somogy) prelazile u Slavoniju u ranije doba. ${ }^{27}$

Argumentacija Attile Zsoldosa uvjerljiva je, no po mom mišljenju gornja slika se u manjoj mjeri može dalje nijansirati. Naime, pojedini tragovi ukazuju na to da o čvrstoj mađarskoj vlasti i poglavito o više-manje izgrađenoj područnoj upravi sredinom 11. stoljeća možemo govoriti samo vezano za područja između Drave i Save, kasnije Slavonije. O šesnaest kasnijih slavonskih županata ${ }^{28}$ (comitatus [castri], mađt. várispánság) govori podatak iz 13. stoljeća, od kojih je jedanaest imalo središte, po kojem su nazvane, sjeverno od Save..$^{29}$ Osim toga, od tih jedanaest županata sedam ih se može smjestiti na području Križevačke županije (mađ. Kőrös megye) 13. stoljeća, ${ }^{30}$ koja u to vrijeme nije čak nije ni doticala državnu granicu. Ti županati uglavnom u kasnijim vremenima nisu postali samostalnim županijama: u 12./13. stoljeću njihov je razvoj prekinut i izgubile su svoj prijašnji značaj. Izgradnju tako guste mreže utvrda najviše je moglo motivirati to da je u pretpostavljenu vremenu nastanka županija jugozapadna obrambena linija trajnije uređena između Drave i Save. Nakon osvajanja Hrvatske 1091. očigledno ne bi bilo nikakva razloga u okolici Drave i Save u širokom pojasu učvrstiti prisutnost oružanih snaga, stoga imamo osnovana razloga smjestiti nastanak većine ovdašnjih županata u 11. stoljeće. Upravu tog područja prvi su ugarski kraljevi temeljito organizirali: isprva se tu vjerojatno protezala županija Kolon, a potom, nakon njezina raspada, vjerojatno oko 1060., županije Zala i

27 Attila Zsoldos, Egész Szlavónia bánja [Ban čitave Slavonije], u: Analecta mediaevalia I. Tanulmányok a középkorról [Analecta mediaevalia I. Studije o srednjem vijeku], ur. Tibor Neumann, sv. 1, Piliscsaba Budapest 2001., str. 274-277.

28 Historiografija na mađarskom jeziku jasno razlikuje dvije vrste srednjovjekovnih teritorijalnih jedinica na koje je bio podijeljen prostor Ugarske i kasnije Ugarsko-Hrvatskog Kraljevstva, a koje izvori razlikuju pod latinskim terminima comitatus (mađ. megye) i comitatus castri (mađ. várispánság). Hrvatska historiografija nije toj terminološkoj (i sadržajnoj) razlici između tih teritorijalnih jedinica poklonila veću pažnju te termin za potonji tip jedinice još nije jednoznačno usvojen. U ovom prijevodu odlučili smo se koristiti termin županat, na isti način na koji je korišten u knjizi Éve B. Halász i Suzane Miljan, Diplomatarium comitum terrestrium Crisiensium (1274-1439). A körösi comes terrestrisek oklevelei (12741439). Isprave križevačkih zemaljskih župana (1274.-1439.), Subsidia ad historiam medii aevi Hungariae inquirendam, sv. 6, Budapest - Zagreb 2014. (op. uredništva).

29 Čazma, Garić, Garešnica, Grđevac, Kalnik, Križevci, Moravče, Rovišće i Zagreb, odnosno utvrde varaždinske i zagorske županije koje se nalaze na desnoj obali Drave, ali koje su - sjeverozapadno od nje - isprva ostale izvan granica slavonske pokrajine organizirane u 12. stoljeću (Attila Zsoldos, Magyarország világi archontológiája 1000-1301. [Svjetovna arhontologija Ugarske 1000.-1301.], História Könyvtár - Kronológiák, adattárak, sv. 11, Budapest 2011., str. 153-154, 164, 168, 180, 187, 221, 228, 271). Gyula Kristó ovamo ubraja i županate Glavnice, Kalnika, Vukovara i Kovazda (Kristó, A feudális széttagolódás, str. 131). Međutim, gradokmetovi (iobagiones castri) Glavnice spomenuti 1259. (CD 5, str. 151) prema ispravi iz 1275. zapravo su vjerojatno puk utvrde Moravče (CD 6, str. 122-123), Kemnuk koji se spominje u ispravi iz 1265. vezano uz kalničku županiju utvrde najvjerojatnije je istovjetan s Kalnikom (CD 5, str. 331; usp. RA, br. 1433), a Vukovar i danas nestali baranjski Kovazd daleko su izvan Slavonije u srednjovjekovnom smislu riječi.

30 Čazma, Garić, Garešnica, Grđevac, Kalnik, Križevci i Rovišće (Zsoldos, Archontológia, str. 153-154, 164, $180,187,271)$. 
Šomođ protežu se i na desnu obalu Drave, ${ }^{31}$ te su zadaću pogranične obrane obavljali županati podređeni tim dvjema zadunavskim županijama. Pojas između Save i Gvozda sredinom 11. stoljeća najvjerojatnije je još pripadao rijetko naseljenoj zoni pogranične obrane onodobne mađarske države (lat. indagines, mađ. gyepú). Naime, o većim, ali vjerojatno rijetko naseljenim područjima prekosavske Slavonije podataka na raspologanju imamo bitno manje, a na tom području spominje se kasnije ukupno pet županata. ${ }^{32}$ To možda pokazuje da se ugarska vlast tu vjerojatno uspostavila mnogo kasnije nego na području sjeverno od Save. Nije nemoguće da je slabo naseljeno područje između Save i Gvozda koje je prije bilo pod labavom mađarskom upravom sveti Ladislav stavio pod stroži nadzor malo prije 1091., kao pripremu za pohod u Hrvatsku - no, u nedostatku izvora to razmišljanje nije ništa više od izuzetno nepouzdane pretpostavke.

\section{Osnutak Zagrebačke biskupije}

Do druge polovine 19. stoljeća znanost je smatrala jasnim da je Zagrebačku biskupiju, koja gotovo točno pokriva područje kasnosrednjovjekovne Slavonije, sveti Ladislav osnovao vjerojatno nakon osvajanja primorske Hrvatske $1091 .^{33}$ Kada je Bálint Hóman raskinuo s tom predodžbom, ${ }^{34}$ Ferdo Šišić je s hrvatske strane stupio s njim u raspravu, ${ }^{35}$ ali kako je stručni dijalog i tu prekinut izbijanjem Prvoga svjetskog rata, otvoreno pitanje o okolnostima osnutka Zagrebačke biskupije također je skrenulo hrvatsku i mađarsku znanost na posve drugi kolosijek, premda rezultati obiju strana ni $\mathrm{u}$ tom razdoblju nisu bili posve nepoznati znanstvenicima. ${ }^{36} \mathrm{U}$ nastavku bih prvenstveno želio predstaviti svoje stajalište o godini osnutka ${ }^{37}-\mathrm{i}$ to $\mathrm{u}$ prvom redu zato što je nastanak Zagrebačke biskupije po mom mišljenju u uskoj vezi s pripremama svetog Ladislava za pohod u Hrvatsku.

Bálint Hóman je bio prvi istraživač koji je moguću godinu osnutka prekodravske biskupije pokušao odrediti ne polazeći od općepovijesnih obrazloženja, već na temelju zabilješke iz 1134. (poznate pod uobičajenim, no netočnim nazivom: Presuda

31 Attila Zsoldos, Somogy vármegye kialakulásáról [O postanku šomođke županije], u: Szent István és az államalapítás [Sv. Stjepan i izgradnja države], ur. László Veszprémy, Budapest 2002., str. 437.

32 Dubica, Gora, Gorica, Oklić i Podgorja - no, moramo napomenuti da s područja županije Vrbasa i Sane nije sačuvan nijedan podatak o županatu (Zsoldos, Archontológia, str. 148, 155, 177-178, 181, 201). Potrebna su daljnja istraživanja da bi se moglo utvrditi radi li se o drukčijem modelu organiziranja županija ili samo o iskrivljenoj slici zbog očuvanja samo nekih izvora.

33 Pauler, Horvát-Dalmátország, str. 200; isti, A magyar nemzet 1, 170, $451-452$ (bilj. 341).

34 Hóman, A zágrábi püspökség, str. 100-113.

35 Šišić, Priručnik, str. 358-369.

36 N. Klaić, Povijest Hrvata, str. 499-500; Josip Buturac - Antun Ivandija, Povijest katoličke crkve među Hrvatima, Zagreb 1973., str. 67; Franjo Šanjek, Kršćanstvo na hrvatskom prostoru. Pregled religiozne povijesti Hrvata (7-20. st.), Zagreb 1991., str. 65; Mile Vidović, Povijest crkve u Hrvata, Split 1996., str. 107. Osnutak prije 1091. pretpostavlja: Lelja Dobronić, Biskupski i kaptolski Zagreb, Zagreb 1991., str. 11.

37 Podrobnije vidi u: Körmendi, A zágrábi püspökség, str. 329-341. 
ostrogonskog nadbiskupa Felicijana) $)^{38}$ o osnivanju biskupije. ${ }^{39}$ Kao što je poznato, isprava ne spominje vrijeme osnutka koje se zbilo desetljećima prije, no spominje imena kraljevskih kapelana koji su surađivali u izgradnji nove dijeceze, kao i dvorjanike od kojih je kralj tražio savjet. Hóman je usporedbom ostalih podataka o osobama navedenima u zabilješci pronašao da je do osnutka Zagrebačke biskupije vjerojatnije došlo prije pohoda svetog Ladislava u Hrvatsku nego poslije njega: to je zaključio prvenstveno iz činjenice da - u tekstu spomenutog - palatina Gyulu, osim ovdje, naši izvori spominju samo 1075. i oko 1089./1090., dok 1091. palatinsku čast obnaša izvjesni Petar. To su stajalište s hrvatske strane, među ostalima i Ferdo Šišić, ${ }^{40}$ Miljenko Pandžićc ${ }^{41}$ te Lujo Margetićt ${ }^{42}$ ozbiljno kritizirali, jer Hóman zapravo nije uspio dokazati da nakon pohoda svetog Ladislava u Hrvatsku palatin imenom Gyula nije mogao opet stupiti u službu. No, arhontološke podatke o karijeri palatina Gyule spomenutog u zabilješci iz 1134. svejedno držim značajnim argumentom koji potvrđuje raniji osnutak. Naravno, u načelu je zamislivo da Gyula, spomenut 1075., nije istovjetan s velikodostojnikom slična imena koji je igrao ulogu u osnutku Zagrebačke biskupije ili da je isti palatin Gyula nakon 1091. ponovno došao na položaj na kraljevskom dvoru, no, uopće ne raspolažemo podatkom koji bi potkrijepio takvo mišljenje.

Hóman je smatrao da su osobe spomenute $\mathrm{u}$ ispravi iz 1134. u vezi s nastankom prekodravskoga crkvenog sjedišta vjerojatno djelovale između 1077. i 1091.: terminus post quem možemo odrediti samo na temelju stupanja na prijestolje kralja svetog Ladislava (jer upravo iz zabilješke vezane za ime nadbiskupa Felicijana znamo da se osnivanje biskupije veže za njegovo ime). ${ }^{43}$ Osobno, međutim, smatram da je moguća i točnija datacija. Fabijan koji je pri osnutku Zagrebačke biskupije surađivao kao nadbiskup u Bácsu vjerojatno je istovjetan s prepoštom slična imena koji je prema legendi o svetom Emeriku ${ }^{44}$ 1083. još bio na čelu stolnobiogradske crkve. To samo po sebi ukazuje na to da Fabijan prije 1083. nije mogao biti nadbiskup. Osim toga, nebeski patron Zagrebačke biskupije kroz cijeli je srednji vijek bio kralj sveti Stjepan, a očigledno mu u čast ne bi bili posvetili crkvu prije nego što je kanoniziran 1083. Nema traga ni tomu da se patrocinij biskupije promijenio bilo koncem 11. stoljeća, bilo u kasnijim razdobljima. Dakle, možemo biti sigurni u to da Zagrebačku biskupiju sveti Ladislav nikako nije mogao uspostaviti prije 1083.: vrijeme osnutka moramo smjestiti u razdoblje između 1083. i 1091.

\footnotetext{
8 DHA 1, str. 261.

39 Hóman, A zágrábi püspökség, str. 100-107, 113.

40 Šišić, Priručnik, str. 358-369.

41 Pandžić, Godina osnutka, str. 161-170.

42 Margetić, Pitanja, str. 254-256.

43 Hóman, A zágrábi püspökség, str. 107.

44 SRH 2, str. 459.
} 
Uže razdoblje osnutka Hóman je odredio polazeći od toga da je Zagrebačka biskupija po njemu imala važnu ulogu u pripremama ekspanzije u smjeru hrvatskih područja. Na odnos između dva događaja želio bih se osvrnuti i u ovom radu, no vrijedi nam napomenuti da se, prema Hómanu, sveti Ladislav počeo baviti mišlju o pohodu na primorje tek nakon smrti svoga šogora, kralja Zvonimira. ${ }^{45}$ Mađarski je povjesničar u skladu s tim uže razdoblje odredio između 1087. i 1090. Njegov je tijek misli nedvojbeno logičan, no ima i nekih materijalnih pogrešaka: Zvonimir nije preminuo 1087., već tek 1089. S tim u skladu, vjerojatno razdoblje osnutka Zagrebačke biskupije po mom mišljenju moramo smjestiti ne između 1087. i 1090., već u godinu 1089. ili 1090.

\section{Okolnosti vojnog pohoda svetog Ladislava u Hrvatsku}

O pohodu svetog Ladislava u Hrvatsku imamo nažalost veoma malo jasnih podataka. Ugarski je vladar u ljeto 1091. uputio pismo opatu Oderiziju u Montecassino - u kojem se nalazi slavna opaska po kojoj je "već osvojio zamalo cijelu Slavoniju"46 - koje je vjerodostojno i pouzdano, no o pohodu taj izvor, nažalost, ne govori. Slično možemo vrednovati i ispravu zadarskog priora Drage, izdanu također 1091., u kojoj datacija ukazuje na to da je ugarski vladar u toj godini osvojio Hrvatsku i ondje za kralja postavio svog nećaka Almoša. ${ }^{47}$ Pripovjedni su izvori opsežniji, no teže se mogu smatrati pouzdanima. Prema svjedočanstvu 132. poglavlja spomenute Bečke ilustrirane kronike najvjerojatnije je nastala u najmanje dvije faze ${ }^{48}$ povrh toga nije sastavljena na temelju činjeničnih podataka, već je konstruirana na fiktivnim osnovama desetljećima poslije samih događaja, na temelju 99. poglavlja kronike. ${ }^{49}$ Također, 137. poglavlje iste kronike samo u dijelu rečenice ukazuje na to da je u trenutku napada Kumana na tamiško pograničje Ugarske 1091. kralj Ladislav upravo bio u "Slavoniji". ${ }^{50}$ Izvještaj Tome Arhiđakona - koji možemo pročitati u 17. poglavlju njegova djela ${ }^{51}$ - većinom se po svemu sudeći temelji na preuzimanju podataka neke

45 Hóman, A zágrábi püspökség, str. 113.

46 Sclavoniam iam fere totam acquisivi (DHA 1, str. 272). Moramo napomenuti da ovdje naziv "Slavonija" po svemu sudeći znači samo "zemlju Slavena (ili u našem slučaju Hrvata)”, a ne posavsku pokrajinu u kasnosrednjovjekovnom smislu riječi (usp. Kristó, Feudális széttagolódás, str. 92; Zsoldos, Egész Szlavónia, str. 273).

47 DHA 1, str. 273.

48 SRH 1, str. 406. Kronika se u dva rukopisa na malo mjesta razlikuje.

49 Johannes de Thurócz, Chronica Hungarorum, sv. 2: Commentarii, 1-2. prir. Elemér Mályusz - Julius Kristó, Bibliotheca scriptorum medii recentisque aevorum, Budapest 1988., sv. 2/1, str. 395; Körmendi, Szent László, str. 447-451.

50 SRH 1, str. 412. Tekst ovdje po svemu sudeći pojam "Slavonije" upotrebljava u sličnom značenju (dakle primorskih hrvatskih područja) kao Oderizijev list, a to omogućuje zaključak da je riječ vjerojatno o zabilješci nastaloj približno istodobno s događajima.

51 Thomas Spalatensis, str. 92-94. 
mađarske kronike upitne pouzdanosti, ${ }^{52}$ a djelo splitskog anonima ${ }^{53}$ ponešto varira i proširuje podatke Tome Arhiđakona pojedinostima bez temelja. ${ }^{54}$

$\mathrm{Na}$ temelju kritičkog ispitivanja izvora o pohodu svetog Ladislava u Hrvatsku, sljedeći se podaci čine vjerodostojnima i dokazivima: 1) pohod se nedvojbeno dogodio 1091. (to znamo prvenstveno iz Dragine isprave); 2) u ljeto 1091. kralj Ladislav još nije smatrao da je osvajački pohod završen (jer je opatu iz Montecassina napisao da je osvojio "gotovo cijelu" Slavoniju, to jest, ostalo je neosvojenih područja); 3) od daljnjeg prodora ugarski je vladar vjerojatno morao odustati zbog provale Kumana $\mathrm{u}$ istočnu Ugarsku (podatak Tome Arhiđakona koji o tome govori možemo pročitati u 137. poglavlju Bečke ilustrirane kronike, za koje se smatra da se zasniva na nekom predlošku gotovo suvremenom događajima); 4) nakon vojnog pohoda kralj Ladislav je svog nećaka Almoša postavio na čelo osvojenih područja kao hrvatskog kralja (što se vidi i iz isprave priora Drage).

Samo tih nekoliko činjenica o jednom od najvažnijih vanjskopolitičkih događaja ugarske povijesti 11. stoljeća možemo smatrati manje-više pouzdanima. Oko njih nam valja izvesti zaključke povijesnom rekonstrukcijom.

Postupimo li tako, vrijeme vojnog pohoda možemo najprije smjestiti u proljeće ili rano ljeto 1091.: $\mathrm{s}$ jedne strane zato što je sveti Ladislav gore navedeno pismo opatu Oderiziju najvjerojatnije pisao u ljeto 1091., ${ }^{55}$ a s druge strane zato što, kad je iste godine - vjerojatno 1. rujna - posvećena opatija u Somogyváru, Ladislav ne samo da je već izvršio pohod u Hrvatsku nego je i očitao lekciju Kumanima koji su mu napali zemlju. ${ }^{56}$ Nakon Zvonimirove smrti 1089., što je omogućilo poduzimanje toga vojnog pohoda, Hrvatsko Kraljevstvo zapalo je u duboku unutarnjopolitičku krizu, koju je još više otežavala činjenica da je kruna dospjela Stjepanu II., koji se tada već činio potpuno nesposobnim za vladanje. Ne samo da taj stari i bolešću iscrpljen čovjek $^{57}$ nije mogao nastaviti uspješnu politiku svog prethodnika nego nije bio sposo-

52 János Karácsonyi, A horvát történetírás zátonyai I. [Grebeni hrvatske historiografije I.], Századok, sv. 47, Budapest 1912., str. 2-3; Isidor Kršnjavi, Zur Historia Salonitana des Thomas Archidiaconus von Spalato, Zagreb 1900., str. 22-24; Šišić, Priručnik, str. 308-309, 564-565. Usp. József Deér, A magyar törzsszövetség és patrimoniális királyság külpolitikája [Vanjska politika mađarskog plemenskog saveza i patrimonijalnog kraljevstva], Kaposvár 1928., str. 87; Körmendi, Szent László, str. 454-458.

53 Šišić, Priručnik, str. 321.

54 Deér, A magyar törzsszövetség, str. 84-85 (bilj. 211). O svemu detaljnije vidi: Körmendi, Szent László, str. $444-460$.

55 DHA 1, str. 272

56 Moje je mišljenje u biti istovjetno s onim Gyule Paulera, premda sam do istog rezultata došao drugim putem. Pauler je vojni pohod smjestio u prvu polovinu 1091. jer je, po njemu, Dragina isprava vjerojatno izdana u srpnju dotične godine (Horvát-Dalmátország, str. 207-208; isti, A magyar nemzet, str. 446 [bilj. 313]). Osobno smatram da je Dragina isprava najvjerojatnije nastala zapravo između 25. i 31. prosinca 1091. (Körmendi, Szent László, str. 445-447).

57 Stjepan se već 1078. povukao u samostan pozivajući se na narušeno zdravstveno stanje (CD 1, str. 164), no budući da se ne čini nemogućim da knez kao jedini Zvonimirov takmac vrijedan spomena nije samoinicijativno odabrao samoću splitskog samostana svetog Stjepana Prvomučenika, vjerodostojnost tog podatka po mom mišljenju nije oslobođena sumnje. 
ban ni očuvati jedinstvo svoje zemlje. Tijekom njegove kratke vladavine kraljevska je vlast u Hrvatskoj po svemu sudeći postala nominalnom: vjerojatno se osamostalila okolica Neretve i okolica Knina (Tennen), koji se prije smatrao vladarskim središtem. ${ }^{58}$ Iz naših se izvora ne vidi čak ni do kada je Stjepan II. nosio kraljevski naslov. Vjerojatno je preminuo još 1090. (eventualno početkom 1091.), ${ }^{59}$ premda načelno nije nezamislivo ni to da su ga otjerale upravo postrojbe svetog Ladislava.

Prema 132. poglavlju Bečke ilustrirane kronike vladara je pozvala u pomoć njegova sestra Jelena, Zvonimirova udovica. Toma Arhiđakon, pak, izvještava da su hrvatski velikaši zamolili kralja Ladislava da uspostavi red. U biti se nijedan podatak ne može potvrditi, štoviše, uzevši u obzir kritičke probleme koje sam već spomenuo vezano za ta dva izvora, osobno smatram veoma spornim da je sveti Ladislav imao ikakvu drugu motivaciju osim osvajačke namjere - no, u nedostatku vjerodostojnih izvora danas je teško jasno odgovoriti na to pitanje. Suprotno tomu, nedvojbeno je da je ugarski kralj s najvećom mogućom pažnjom odabrao vrijeme napada. Naime, Ladislav nije pokrenuo svoju vojsku u boj neposredno nakon Zvonimirove smrti, već tek dvije godine poslije, kada su gotovo svi uvjeti pogodovali njegovim planovima kako na hrvatskim područjima, tako i u njihovoj široj okolici. U Hrvatskoj se do tog trenutka zbog unutarnjopolitičke krize središnja vlast potpuno raspala, ${ }^{60}$ pa za borbu protiv ugarske vojske pod jedinstvenim vodstvom nije bilo značajne domaće vojne sile sposobne za usklađenu vojnu akciju. Prema našim saznanjima, vanjskopolitički odnosi područja sjevernog Jadrana također su se upravo do početka 1091. razvili tako da nijedna od ostalih sila koje su gajile ambicije prema hrvatskim područjima i dalmatinskim lučkim gradovima nije mogla poduzeti mjere protiv ugarskog osvajanja. Venecija je možda još patila od posljedica teškog poraza na moru koji su im 1084. nanijeli Normani. ${ }^{11}$ Papinstvo je između 1090. i 1092. prolazilo kroz jedno od najkriznijih razdoblja borbe za investiture, ${ }^{62}$ a Bizant je u proljeće 1091. bio

58 Budak - Raukar, Hrvatska povijest, str. 140-141.

${ }^{59}$ Posljednji spomen iz isprave koji se može datirati potječe iz 1089.: CD 1, str. 190.

60 N. Klaić, Povijest Hrvata, str. 489-491.

${ }_{61}$ Brodovlje Republike Normani su praktički potpuno razorili u blizini Krfa u jesen 1084., što je možda bio dotad najteži poraz mletačke flote (Heinrich Kretschmayr, Geschichte von Venedig, sv. 1-2, Gotha 1905., sv. 1, str. 165). Ana Komnena, doduše, izvještava da su Mlečani još iste godine opremili novu ratnu flotu i uzvratili pobjedom pored Butrinta (Anne Comnène, Alexiade, sv. 1-4, prir. Bernard Leib, Paris 1967.-1989., sv. 2, str. 54), no taj podatak znanost odbacuje jer je, s jedne strane, nevjerojatno da je u takvim odnosima tog razdoblja doista bilo moguće izgraditi jaku ratnu flotu u nekoliko kratkih mjeseci, a s druge strane, $u$ inače veoma podrobnim mletačkim zabilješkama nema ni spomena o toj navodnoj drugoj pomorskoj bitci (John Julius Norwych, Venice: The Rise to Empire, sv. 1-2, London 1977., sv. 1, str. 96).

62 Pred napadom njemačko-rimskog cara Henrika IV. papa Urban II. je 1090. iz Rima pobjegao k savezničkim Normanima u južnoj Italiji i u svoju se prijestolnicu mogao vratiti tek 1093., nakon careva poraza kod Canosse 1092. (Bruno Gebhard - Karl Jordan, Investiturstreit und frühe Stauferzeit 1056-1197., Handbuch der deutschen Geschichte, sv. 4, München 1971.6 , str. 55-56). 
zaokupljen borbama protiv Pečenega. ${ }^{63}$ Te sile, dakle, također nisu bile u situaciji da stanu na put ugarskoj ekspanziji. ${ }^{64}$ Ladislav je vjerojatno isprva planirao i pokoravanje dalmatinskih gradova: nije isključeno da je opasku o nedovršenosti osvajanja u pismu upućenu opatu Oderiziju potaknula činjenica da zbog napada Kumana nije bio u mogućnosti osvojiti priobalje.

Događaji i trase vojnog pohoda ne mogu se, nažalost, rekonstruirati..$^{65} \mathrm{O}$ opsegu osvojenog područja naši izvori ne govore, možda je vojska svetog Ladislava zauzela prvenstveno područje Gvozda i Velebita. ${ }^{66} \mathrm{U}$ prijašnjem je mađarskom povijesnom istraživanju postojalo gledište koje je jednoznačno pripisivalo i osvajanje Biograda na Moru svetom Ladislavu. ${ }^{67}$ Međutim, nikakav izvor ne ukazuje na osvajanje te jadranske luke, prijestolnice Hrvatskog Kraljevstva. No, možemo biti sigurni u to da dalmatinski gradovi 1091. još nisu dospjeli pod mađarsku upravu. To prvenstveno dokazuje isprava priora Drage. Svjedočanstvo diplome koju je izdao zadarski čelnik osobito je vrijedno jer je diploma izdana u jednom od najvažnijih dalmatinskih gradova u godini vojnog pohoda, dakle izvor je nastao gotovo istodobno s događajem. U datumu je na prvom mjestu godina vladanja bizantskog cara Aleksija, što samo po sebi jasno potvrđuje da je mjesto izdavanja isprave pod upravom bazileja, a ne ugarskog kralja. Uz to, ista isprava spominje samo pohod ugarskog kralja u Hrvatsku (Croatię invadens regnum), ne spominje osvajanja u Dalmaciji. ${ }^{68}$ Osim toga znamo da je u drugoj polovini 1091. Bizant proširio vlast na primorske lučke gradove. ${ }^{69}$

Iz isprave zadarskog priora Drage također znamo da, nakon što je osvojio Hrvatsku, sveti Ladislav "ondje je postavio za kralja svoga nećaka, gospodina Almoša."70

63 Pečenezi koji su duž dunavske granice carstva godinama predstavljali veliku opasnost, u proljeće 1091. sklopili su savez s Cahasom, Emirom Čakom od Smirne i prodrli gotovo do Konstantinopola. Vidi: Louis Bréhier, Bizánc tündöklése és hanyatlása [Uspon i pad Bizanta], Varia Byzantina - Bizánc világa, sv. 1, Budapest 1999.2. str. 283-284.

64 Körmendi, Szent László, str. 462-466. Usp. Deér, A magyar-horvát, str. 35-36.

65 Prema Gyuli Pauleru Ladislavova vojska vjerojatno je išla ratnom trasom koja je i u kasnije doba Arpadovića povezivala središnja područja Ugarske i jadransku obalu. Tu je trasu Pauler rekonstruirao na temelju podataka pretežno iz 13. stoljeća (Pauler, Horvát-Dalmátország, str. 212; isti, A magyar nemzet, sv. 1, str. 156-157). Međutim, ozbiljan nedostatak njegove privlačne pretpostavke jest da je ne potkrepljuje nikakav onodobni izvor - a koliko se god logičnom idejom čini poći od relativne nepromjenjivosti srednjovjekovne mreže prometnih putova, koja se prilagođava reljefu i hidrografskim značajkama, kasnija su istraživanja kod nemalo pojedinosti doveli u pitanje Paulerovu rekonstrukciju. Vidi: Lajos Glaser, Dunántúl középkori úthálózata I. [Srednjovjekovna mreža puteva u Transdanubiji], Századok, sv. 113, Budapest 1929., str. 143-145. György Györffy (vjerojatno se uglavnom oslanjajući na Paulerovu spomenutu pretpostavku) već je smatrao vjerojatnim da je glavnina ugarske vojske koja je krenula na Hrvatsku napredovala sve do jadranskih obala, ondje zauzela Biograd na Moru, a pomoćne su postrojbe dijelom osvojile hrvatsko gorsko područje i Knin, a dijelom istočni dio Bosne. Vidi: György Györffy, A "lovagszent" uralkodása (1077-1095) [Vladavina "viteškog sveca" (1077.-1095.)], Történelmi Szemle, sv. 20, Budapest 1977., str. 558. Međutim, naši izvori ne potvrđuju nijedan element te ideje.

66 Pauler, Horvát-Dalmátország, str. 208; isti, A magyar nemzet, sv. 1, str. 157.

67 Györffy, A "lovagszent", str. 558.

68 DHA 1, str. 273.

69 Deér, A magyar-horvát, str. 39.

70 [...] domnum Almum, suum nepotem in illo statuit regem (DHA 1, str. 273). 
Krenemo li od samih događaja, čini se logičnim misliti da je Almoševa krunidba održana vjerojatno u trenutku kada se Ladislav na vijest o napadu Kumana morao vratiti u Ugarsku. ${ }^{71}$ No, vlast se kralja Almoša u svjetlu izvora čini iznenađujuće ograničenom. Ladislav u pismu upućenu Oderiziju govori o osvajanjima u Hrvatskoj, no ni jednom riječju ne spominje svog nećaka, a ni često citirana opaska po kojoj "sam već osvojio gotovo cijelu Slavoniju" ne ukazuje pretjerano na ugarskog kralja koji je voljan dijeliti vlast $\mathrm{s}$ nekim. ${ }^{72}$ Povrh toga, Ladislav $\mathrm{u}$ istom pismu isključivo u vlastito ime obećaje nova darovanja koja namjerava učiniti u čast svetog Egidija u "Slavoniji", a pritom uopće ne spominje eventualnu suradnju svoga nećaka. Ako je doista točno da je Almoš nosio naslov hrvatskog kralja već i u vrijeme nastanka pisma Oderiziju, onda mu je stric ostavio uistinu malo slobodnog političkog prostora, čak i u odnosu na razinu vazalnih kraljevstava. ${ }^{73}$

\section{Mjesto vojnog pohoda svetog Ladislava u Hrvatsku u vanjskoj politici onodobne ugarske države}

U prvim godinama vladavine vanjska politika kralja Ladislava bila je pod pritiskom. Stalnu opasnost za legitimaciju njegove vlasti predstavljao je Salomon kojeg je knez Gejza upravo s Ladislavovom pomoći zbacio s prijestolja 1074. i koji do kraja života nije odustao od preuzimanja vlasti nad zemljom. Salomon je do početka osamdesetih godina 11. stoljeća u sukobu papinstva i carstva - koji je u to vrijeme temeljito odredio političke odnose moći u tom području - uživao podršku rimskonjemačkog kralja (od 1084. cara) Henrika IV., pa se Ladislav i unatoč tomu vjerojatno orijentirao samo prema papi, iako mu je, kako to svjedoče njegovi postupci i mjere, idejni sustav gregorijanizma bio izuzetno dalek. No, Salomon je 1087. preminuo, čime je odjednom nestao i izvor opasnosti koji je Ladislava doveo u sukob s Henrikom IV. i tako ga nužno natjerao u tabor Urbana II. Ugarski vladar od tada vjerojatno više nije nastojao osigurati pozicije svoje zemlje uz obvezujuću podršku reformiranog svećenstva, već se trudio provoditi uravnoteženu vanjsku politiku koja bi omogućila mirne odnose is carem i s papom. ${ }^{74}$

Naspram te oprezne vanjske politike pohod u Hrvatsku je nedvojbeno nosio ozbiljne opasnosti. Naime, godine 1076. kralj Zvonimir je prisegnuo na vjernost papi, ${ }^{75}$ pa je ugarsko osvajanje 1091. u načelu kršilo i prava Svete Stolice. ${ }^{76}$ Povrh toga, papa

71 Ferenc Makk, Magyar külpolitika (896-1196) [Ugarska vanjska politika], Szegedi Középkortörténeti Könyvtár, sv. 2, Szeged 1996. ${ }^{2}$, str. 131.

72 DHA 1, str. 272.

73 O svemu podrobnije vidi u: Körmendi, Szent László, str. 443-477.

74 Deér, A magyar törzsszözetség, str. 88-91; Makk, Magyar külpolitika, str. 123-124.

75 CD 1, str. 139-140. O točnoj dataciji Zvonimirove krunidbe i zakletve vidi: Jakov Stipišić, Pitanje godine krunidbe kralja Zvonimira, u: Zvonimir, kralj hrvatski, ur. Ivo Goldstein, Zagreb 1997., str. 57-66.

76 Deér, A magyar törzsszövetség, str. 90; Györffy, A "lovagszent", str. 556; Makk, Magyar külpolitika, str. 133. 
Urban II. je od samog stupanja u službu želio urediti odnose Rima i Bizanta ${ }^{77}$ - dakle, po svemu sudeći sve je u jadranskoj regiji bilo pogodno za sklapanje saveza koji bi Urbana II., čija su seniorska prava u Hrvatskoj prekršena, ujedinio s carem Aleksijem I. koji je provodio nominalnu vlast nad dalmatinskim područjima (i Mlečanima koji su mu saveznici) protiv kralja Ladislava i Ugarske koji provaljuju u primorje. No, nakon pohoda u Hrvatsku ne samo da opisani savez nije sklopljen nego, dapače, ni diplomatski odnosi između Urbana II. i svetog Ladislava nisu prekinuti (ili barem ne odmah). Naši podaci jasno pokazuju da je u mjesecima nakon vojnog pohoda između Ugarske i Svete Stolice tekao živ diplomatski promet. ${ }^{78}$ Za tu naizgled proturječnu situaciju pružaju se tri moguća objašnjenja.

Kao prvo, prema stajalištu Ferenca Makka, kralj Ladislav je poslao poslanika k Svetoj Stolici kako bi zatražio naknadnu suglasnost za osvajanje Hrvatske - a poslanstvu kardinala Teuzona, koje je poslano u Ugarsku upravo 1091. (radi posvete opatije u Somogyváru), vjerojatno je pravi cilj bio da Ladislav prizna papinsko pravo u Hrvatskoj. Ugarski vladar to nije bio voljan učiniti, pa je odnos između papinstva i Ugarske zahladio. ${ }^{79}$

Kao drugo, moguće je da Urban II. na pohod kralja Ladislava u Hrvatsku nije reagirao agresivnije možda zbog toga što $u$ dotičnom trenutku nije raspolagao potrebnom silom. Godine 1090. (dakle, u godini koja je prethodila pohodu) Car je izgnao papu, koji je potom potražio utočište kod Normana, čak i iz Rima te se u svoju prijestolnicu mogao vratiti tek kad su njegovi sjeverno-talijanski saveznici 1092. kod Canosse porazili Henrika IV. Samoj ugarskoj ekspanziji papinstvo se možda nije ni protivilo, jer teško da je moglo stvarno ostvarivati svoja seniorska prava u političkom kaosu koji je vladao u Hrvatskoj dovedenoj na rub raspada. Dakle, diplomacija Svete Stolice eventualno je i podržavala ugarski prodor koji stvara uređenije unutarnjopolitičke odnose, a potom je radi ostvarivanja svojih seniorskih prava preko kardinala Teuza pokušalo navesti kralja Ladislava da kao gospodar hrvatskih područja on ili Almoš prisegnu na vazalstvo Urbanu II. ${ }^{80}$ Ladislav naravno nije pristao na vazalstvo. Slijedom toga odnosi su između Svete Stolice i Ugarske vjerojatno olabavjeli (no, teško da su se prekinuli), a Ladislav se u vanjskoj politici okrenuo prema carstvu intenzivnije nego prije. ${ }^{81}$

77 Bréhier, Bizánc tündöklése, str. 287-289.

78 DHA 1, str. 268-269, 272.

79 Makk, Magyar külpolitika, str. 134.

80 Makk, Magyar külpolitika, str. 134.

81 Prema Gáboru Vargi papinstvo nije zamjeralo izostanak vazalske prisege, nego pohod ugarskog kralja u Hrvatsku nisu priznali zato što bi time ugrozili odnos - koji je pod pontifikatom pape Urbana II. krenuo nabolje - između Svete Stolice i Bizanta. Vidi: Gábor Varga, Ungarn und das Reich vom 10. bis zum 13. Jahrhundert. Das Herrscherhaus der Árpáden zwischen Anlehnung und Emanzipation, Studia Hungarica, sv. 49, München 2003., str. 147. 
I kao treće, po mom mišljenju ne možemo biti posve sigurni ni u to da je papinsko vazalstvo, nedvojbeno prihvaćeno 1076. ${ }^{82}$ doista i bilo na snazi u Hrvatskoj u godinama neposredno prije pohoda kralja Ladislava. Godine 1089. ili 1090. na splitskom saboru nazočili su hrvatski kralj Stjepan II. i više svjetovnih velikodostojnika, ${ }^{83}$ što je u suprotnosti s principima gregorijanske reforme koja općenito nije podržavala sudjelovanje laika na crkvenim saborima. Ako se, međutim, u onodobnoj Hrvatskoj vladar i viši kler nisu nužno pridržavali ideja reformiranog svećenstva ni u pitanjima crkvene uprave, možda s razlogom možemo dovesti u pitanje bi li u političkim pitanjima i stvarno prihvatili nadležnost Svete Stolice. Ako je, pak, papinstvo bilo vezano za Hrvatsku možda ionako samo nominalnim interesima, savršeno je razumljivo da zbog istih nisu željeli ući u novi vanjskopolitički konflikt u jeku oštrih borbi za investituru. U tom slučaju razlog sukoba koji se između Ugarske i Svete Stolice kasnije stvarno i odigrao možda je činjenica da je Ladislav izgrađivao sve bolje veze s carom Henrikom IV.

Koje od gore navedenih objašnjenja stoji (ako uopće ijedno od njih stoji), u nedostatku jasnih izvornih podataka nemoguće je utvrditi. Međutim, sigurno je da je sveti Ladislav mogao hrvatska područja osvojena oružjem zadržati i diplomatskim sredstvima - što opet pokazuje da je ugarski kralj savršeno odabrao pravo vrijeme za napad i nepogrešivo odmjerio odnose moći u regiji.

Kako se pohod u Hrvatsku, nakon svega navedenoga, može smjestiti u vanjsku politiku onodobne ugarske države? Sveti Ladislav je u godinama nakon Salomonove smrti provodio izuzetno aktivnu, štoviše, jasno ekspanzijsku vanjsku politiku. U drugoj polovini osamdesetih godina, možda oko 1089., središte je Kaločke nadbiskupije smjestio u mnogo južniji Bač, ${ }^{84}$ i ne čini se nevjerojatnim mišljenje da je time možda želio utrti put ekspanzije u donjem Podunavlju. ${ }^{85}$ Nakon prodora u Hrvatsku, prvo je godine 1092. vodio pohod protiv kneza Vasilka od Terebovlja, ${ }^{86} 1094$. s oružjem se upleo u borbe za prijestolje u Krakovu, ${ }^{87}$ a 1095. se pripremao za sličan

82 CD 1, str. 139-140.

83 CD 1, str. 191. O tom saboru, vidi više u: Lothar Waldmüller, Die Synoden in Dalmatien, Kroatien und Ungarn von der Völkerwanderung bis zum Ende der Árpáden (Konziliengeschichte. Reihe A: Darstellungen), Paderborn - Wien - Zürich - Schöningh 1987., str. 95-96.

84 Gábor Thoroczkay, A kalocsai érsekség első évszázadáról [O prvom stoljeću Kaločke nadbiskupije], u: isti, Írások az Árpád-korról. Történeti és historiográfiai tanulmányok [Spisi o arpadovskom razdoblju. Studije iz povijesti i historiografije], Budapest 2009., str. 61-64.

85 Ferenc Makk, A kalocsai érsekség bácsi székhelyének létesítéséről [O uspostavi bačkog sjedišta kaločke nadbiskupije], u: Kalocsa történetéból [Iz povijesti Kaloče], ur. László Koszta, Kalocsa 2000., str. 21-27. Istodobno, prema drugim mišljenjima razlog je premještaja prijestolnice jednostavno bio taj da je vladar želio učvrstiti upravu u rubnim dijelovima kraljevstva (László Koszta, Dél-Magyarország egyházi topográfiája a középkorban [Crkvena topografija južne Ugarske u srednjem vijeku], u: A középkori Dél-Alföld és Szer [Srednjovjekovni Južni Alföld i Szer], ur. Tibor Kollár, Dél-alföldi évszázadok, sv. 13, Szeged 2000., str. 44-45).

86 Márta Font, Árpád-házi királyok és Rurikida fejedelmek [Kraljevi iz kuće Arpadovića i kneževi Rjurikovići], Szegedi középkortörténeti könyvtár, sv. 21, Szeged 2005., str. 99.

87 Makk, Magyar külpolitika, str. 137. 
pothvat na bojištu Češke opterećene unutarnjim sukobima, no zbog njegove smrti taj se posljednji pohod nije dogodio.$^{88}$ Dakle, smrt kralja Salomona 1087. otvorila je posve nove perspektive pred svetim Ladislavom i ugarskom vanjskom politikom, ${ }^{89} \mathrm{a}$ pohod u Hrvatsku bio je najznačajniji i najuspješniji pothvat tog, s vanjskopolitičkog gledišta, izuzetno aktivnog razdoblja. No, postavlja se pitanje koliko ga možemo smatrati modelom pri proučavanju onodobne mađarske vanjske politike, koje nije uzaludno postaviti već i zbog razloga što bi nam odgovor, po mom mišljenju, pomogao bolje razumjeti poveznice između osnutka Zagrebačke biskupije i priprema za ekspanziju u Hrvatsku.

Na temelju rezultata njemačke medievistike, Njemačko Carstvo u nastajanju, a potom oblikovano i učvršćeno Sveto Rimsko Carstvo svoje je ekspanzijske težnje prema istočnim (dakle, poglavito poljskim, češkim i ugarskim) područjima uglavnom pokušalo ostvariti u četiri koraka: 1) slanje svećenika misionara na tada još poganska područja; 2) izgradnju crkvene organizacije podređene carstvu na dotičnom području; 3) vojni prodor; 4) izgradnju političke organizacije i svjetovne uprave.

Pohod svetog Ladislava u Hrvatsku i njegovi neposredni povodi strahovito podsjećaju na taj ekspanzijski model, koji se izvorno naziva otonskim. Prvi je korak u tom slučaju, naravno, bio nepotreban jer se kršćanstvo na hrvatskim područjima duboko ukorijenilo stoljećima prije ugarskog osvajanja. Iz istog razloga nije bilo povoda ni za korjenitu preobrazbu hrvatske crkvene organizacije - istodobno, izgradnja Zagrebačke biskupije na ugarskoj strani nenaseljenog područja pospješila je pripreme za vanjskopolitičku ekspanziju. Vojni prodor bio je sam pohod 1091., a izgradnja političke strukture na čelu koje je ugarski kralj dogodila se iste godine, naime, isprava zadarskog priora Drage iz 1091. naziva Ladislavova nećaka Almoša hrvatskim kraljem. Dakle, pohod svetog Ladislava u Hrvatsku zaslužuje osobitu pozornost ne samo kao daleko najuspješniji pothvat onodobne ugarske vanjske politike i kao početak hrvatsko-ugarske državne zajednice koja je opstala daljnjih osam stoljeća - već i kao iznimno uspješno ostvarenje međunarodno uvriježenoga ekspanzijskog modela toga doba.

Preveli: Lea Kovács i dr. György Lukács B.

\footnotetext{
Makk, Magyar külpolitika, str. 137; usp. Dániel Bagi, Der angebliche Böhmenfeldzug von Ladislaus I. dem Heiligen im Kapitel 140 der Ungarischen Chronikkomposition des 14. Jahrhunderts, Specimina Nova. Pars Prima. Sectio Mediaevalis, sv. 8 (2015.), str. 44.

89 Pauler, A magyar nemzet 1, str. 160-161; Makk, Magyar külpolitika, str. 123.
} 
Tamás Körmendi

\title{
Preparations and Military Campaign of King (St) Ladislas I in Croatia
}

\begin{abstract}
Summary
The paper aims to draw a more precise (or at least more precise) picture about the Croatian campaign of King (St) Ladislas I of Hungary and the establishment of the dioecese of Zagreb. After examinig relevant sources, the author cames to the conclusion that most of the territory situated between the river Drava and the Gvozd mountain could belong, at least loosely, to the Kingdom of Hungary even before the Hungarian conquest of the Kingdom of Croatia. He sets the date of the foundation of the dioecese of Zagreb to 1089/1090, and thinks that the newly established bishopric had to help in some way the preparations for the conquest of Croatia. There are no trustworthy clues or data that could prove that St Ladislas really acted in order to support the widowed queen Helena or to restore the inner peace and order in the country at the request of Croatian noblemen - this is to say, the author rejects on the basis of critical arguments the testimony of Thomas Spalatensis and of the Chronica picta Vindobonensis. Contemporary charters from Dalmatian cities seem not to support the hypothesis that the Kingdom of Croatia was really a vassal of the Holy See in the years around 1089/1090, so the author does not think that the conquest could cause any serious troubles in the relations between the Hungarian royal court and the Papacy. The author concludes that the most probable purpose of the campaign of 1091 was simply wish for territorial gains.
\end{abstract}

Ključne riječi: Ladislas I (St Ladislas); the bishopric of Zagreb; Hungary; Croatia; Slavonia; history of the eleventh century 
